\title{
WestVirginiaUniversity。
}

Department of Economics

Working Paper Series

\section{Nonpublic Competition and Public School Performance: Evidence from West Virginia}

Richard Cebula, Joshua Hall and Maria Tackett

Working Paper No. 15-29

This paper can be found at the College of Business and Economics Working Paper Series homepage: 


\title{
Nonpublic Competition and Public School Performance: Evidence from West Virginia
}

\author{
Richard J. Cebula \\ Walker/Wells Fargo Endowed Chair in Finance \\ Jacksonville University \\ Davis College of Business \\ Jacksonville, FL 32211 \\ rcebula@ju.edu \\ Joshua C. Hall \\ College of Business and Economics \\ West Virginia University \\ Morgantown, WV 26506-0625 \\ 304-293-7870 \\ joshua.hall@mail.wvu.edu \\ Maria Y. Tackett \\ W. Marston and Katharine B. Becker Doctoral Fellow \\ West Virginia University \\ Morgantown, WV 26506-0625 \\ 3042938533 \\ tackettmariay@gmail.com
}

\begin{abstract}
In this study, we investigate whether nonpublic school enrollment affects the performance of public school districts. If homeschooling and private schools act as competition, public school districts test scores should be positively associated with nonpublic enrollment. Using data on West Virginia county school districts, and controlling for endogeneity with an instrumental variables approach, we find that a one standard deviation increase in relative nonpublic enrollment in a county is associated with statistically significant increases in public school district test scores. Our findings thus confirm that nonpublic enrollment and the competition it provides act to improve, rather than impede, public school performance.
\end{abstract}

Key words: competition, markets, education

JEL codes: H52, I28

Acknowledgements: Hall would like to acknowledge that a portion of this work was conducted while he was a Big XII Fellow with the Free Market Institute at Texas Tech University. He also would like to thank the Center for Free Enterprise at West Virginia University for general research and travel support. 


\section{Nonpublic Competition and Public School Performance: Evidence from West Virginia}

\section{Introduction}

The public and private returns to educational attainment are high (Hall, 2000). For that reason, a considerable amount of focus is placed on school performance. In the United States, jurisdictions have increasingly been turning towards school choice as a way of increasing student performance (Berends, 2014). The movement towards school choice has not been without considerable public debate, however, as there are a variety of different perspectives on what the eventual outcome of expanded school choice would actually be. For example, opponents of school choice frequently argue that expanded choice makes the public schools worse off because resources and good peers leave the public schools. ${ }^{1}$ Proponents frequently point out that school choice is often targeted and that competition from private schools and charter schools often improves the performance in public schools. ${ }^{2}$

One way that economists have investigated this issue is to look at the effect of historical forms of school choice: private education and home schooling. States like West Virginia, although they do not have school choice such as public charter schools or voucher programs, do have more traditional school choice in the form of home schooling and private schools. ${ }^{3}$ If competitive forces are in operation with respect to education, areas with more families choosing private education or home schooling should have better performing public schools, other things

\footnotetext{
${ }^{1}$ See, for example, Ravitch (2011).

2 See, for example, Forster (2013).

${ }^{3}$ In addition, there is choice across districts. In West Virginia, however, the size of county districts means that there is less traditional public school 'choice' when compared to states like Ohio where school districts are not required to be at the county level. Ohio has 611 school districts and 88 counties, while West Virginia has 55 counties and 55 school districts.
} 
being equal. This argument has been tested empirically many times. Belfield and Levin (2002)

summarize this literature and find that increased competition (public or nonpublic) generally has been shown to lead to improved performance of public school systems. ${ }^{4}$

In this study, we seek to add to the literature on the question of competitive forces in education by using evidence from West Virginia. The state is an interesting laboratory since it has no public charter schools, no education tax credits, and no voucher programs. In addition, inter-jurisdictional choice is circumscribed due to the fact that the state has large county school districts that make it difficult to exercise 'choice' by moving to an adjoining district while still maintaining a normal commute. We measure competition as the percentage of students in a county attending non-public schools. Our approach here is most similar to Hall and Vedder (2003) and Couch, Shughart, and Williams (1993), who find that competition from nonpublic sources leads to greater public school performance in Ohio and North Carolina, respectively. ${ }^{5}$

To preview our results, we find that competition from private schools and home schooling is associated with increased public school district performance on tests in mathematics, reading, science, and social studies. Our basic results suggest that a one standard deviation increase in nonpublic enrollment relative to public enrollment would lead to an increase in public school test scores ranging from 1.22 to 1.50 percentage points. After instrumenting for nonpublic enrollment using the 1890 value of church property, farms per acre

\footnotetext{
${ }^{4}$ Competition has also been found to lead to other results such as higher public school teacher salaries (Vedder and Hall, 2000). It should be noted that some studies do not find a positive relationship between competition and school performance (Simon and Lovrich, 1996; Sander, 1999; Geller, Sjoquist, and Walker, 2006). More recent papers on the relationship between local school competition and student performance such as Ponzo (2011), Misra et al. (2012), and Thapa (2013) have also found positive results in very different circumstances and situations.

${ }^{5}$ Public choice scholars have a long history of studying education and its' effects. For example, Cebula (1977) looks at how attitudes toward spending affect migration, while Flowers (1975), Akin and Lea (1982), Denzau and Grier (1984), Burnell (1991), Marlow and Orzechowski (1996), Aaberge and Langørgen (2003), Holcombe and Kenny (2007) and Holcombe and Kenny (2008), use schools to look at various public choice aspects related to public expenditures such as the influence of unions and fiscal illusion.
} 
in 1890, and the percentage of a county covered by water, we find that our OLS results are overstated by approximately 10 percent. Our more precise estimates suggest that a one standard deviation increase in nonpublic enrollment in a West Virginia county is associated with between a 1.10 and 1.35 percentage point increase in test scores, ceteris paribus.

\section{Empirical Specification and Data Description}

The empirical model employed to investigate the effect of differences in nonpublic to public school enrollment ratio on test proficiency is given by the following:

$$
\begin{aligned}
& \operatorname{MATH}_{i}=\beta_{0}+\beta_{1} \text { ENROLLRT }_{i}+\beta_{2, \ldots, k} X_{i}+\varepsilon_{i}, \\
& \operatorname{READ}_{i}=\alpha_{0}+\alpha_{1} \text { ENROLLRT }_{i}+\alpha_{2, \ldots, k} X_{i}+\varepsilon_{i}, \\
& \operatorname{SCI}_{i}=\gamma_{0}+\gamma_{1} \text { ENROLLRT }_{i}+\gamma_{2, \ldots, k} X_{i}+\varepsilon_{i}, \\
& \operatorname{SOSCI}_{i}=\delta_{0}+\delta_{1} \text { ENROLLRT }_{i}+\delta_{2, \ldots, k} X_{i}+\varepsilon_{i},
\end{aligned}
$$

The first dependent variable, $M A T H$, is the percentage of students in each school district who have achieved the level of proficiency in the mathematics section of West Virginia Educational Standards Test 2 (WESTEST2). The test is conducted once a year and is designed to evaluate both student performance and educational effectiveness in West Virginia for grades 3-11. Students' knowledge in the following three areas is also tested: Reading and Writing, Sciences, and Social Studies. Accordingly, the following additional three dependent variables are employed in the study: $R E A D$, the percentage of students who are proficient in the reading and writing section of the test; SCI, the percentage of students who are proficient in the science section of the test; and SOSCI, the percentage of students who are proficient in the social studies section of the test. The West Virginia Department of Education provides WESTEST2 assessment data. 
The independent variable of greatest interest is ENROLLRT. It is constructed by dividing enrollment in nonpublic schools by enrollment in public schools for each school district and multiplying the ratio by 100 . West Virginia Department of Education provides data for both types of enrollment. The mean enrollment ratio in the sample is 5.61, meaning that for each 1,000 students enrolled in public schools there are about 56 students enrolled in nonpublic schools (private schools and homeschooling). This data are obtained from the West Virginia Department of Education (2014).

$X$ is a vector of control variables that include school district-related variables, such as spending per pupil (SPEND), average class size (SIZE), salary of the instructional staff (SALARY), and attendance rates (ATTENDANCE). As documented by Belfield and Levin (2002), omitting these variables could lead to omitted-variable ("resource-omission”) bias. In any case, it is noteworthy that Verstegen and King (1998) review an extensive amount of literature of studies that investigate the effects of school spending and other factors on educational outcomes. They conclude that, among other factors, spending per pupil, average class size, and the salary of the instructional staff exercise significant impacts on academic outcomes. ${ }^{6}$ More recently, Cebula et al. (2015) find, using Los Angeles County High Schools as the focus of their study, that higher academic performance is associated with higher teacher salaries. Similarly, academic performance has been shown to be positively associated with attendance rates (Lamdin, 1996; Roby, 2004; Hall, 2006). ${ }^{7}$ All of the school-related variables are for the academic year 20102011 and were obtained from West Virginia Department of Education (2014). We also include

\footnotetext{
${ }^{6}$ Not all papers find a statistically significant relationship between these variables and test scores. For example, Hall (2007) actually finds a negative and statistically significant relationship between district expenditures per pupil and Ohio school district math scores. Hall and Vedder (2003) find a negative, but not statistically significant, relationship between class size and a number of different test scores at the district level in Ohio.

${ }^{7}$ See, for example, Roby (2004).
} 
mean family income within each school district (INCOME) to control for family and household influences that might influence school district performance. ${ }^{8}$ Data on mean family income by county was obtained from the U.S. Census (2014a). Summary statistics for all variables are included in Table 1.

\section{Empirical Results}

Table 2 presents the results of regressing the share of students who are proficient on the math section of WESTEST2 on the ratio of nonpublic to public school enrollment. In the first specification of the table, we control for school-related variables and the average income of each school district. The relationship between nonpublic competition and public school district test scores is statistically significant and positive. In terms of magnitude, a one standard deviation increase in the percentage of nonpublic school students in a county school district is expected, ceteris paribus, to be associated with an increase in the share of students proficient in Math (as documented by public school test scores) at the district level by 1.27 percentage points. ${ }^{9}$ This is about one-fifth of a standard deviation in public school district share of students proficient in Math. So while not quantitatively large in terms of magnitude, it is important to remember that many individuals fear that increases in nonpublic enrollment will make the public schools worse off. Our initial results suggest that this is not the case, at least in West Virginia. ${ }^{10}$

\footnotetext{
${ }^{8}$ Additional demographics available include the percentage of district residents with a bachelor's degree and racial data. These data are highly collinear with mean family income but produce similar results when substituted for income in our regressions. In addition. Hall and Leeson (2010) discuss the difficulty in interpreting a variable such as nonwhite in the context of district level regressions.

${ }^{9} 4.53 \times 0.282=1.277$.

${ }^{10}$ It should also be noted that when a student transfers to a private school or is home schooled, total school spending per pupil usually rises as locally raised revenue does not change (although state revenue that is based on enrollment will be reduced). It is an empirical question whether public school districts are able to achieve cost savings from enrollment declines in the short-run given the lumpy nature of much of their costs, such as teachers or transportation.
} 
The other control variable that seems to be significantly correlated with the West Virginia public school district math scores is the mean family income by school district. This result is similar to what has been found by a number of previous studies in the education production function literature (Hall, 2006; Eide and Showalter, 2012). Its coefficient is statistically significant and positive such that that a one standard deviation in mean family income $(\$ 7,930)$ is associated with a 2.57 percentage point increase in scores, or just over four-tenths of a standard deviation. ${ }^{11}$ Changes in circumstances that affect family income would seem to play a more important role in explaining test scores across counties than school-related variables, given the lack of statistical significance in other variables in Table 2.

To see how robust the findings of Table 2 are, in Table 3 we estimate the same empirical model on all three remaining tests: reading, science, and social studies. For all of the subjects the share of non-public enrollment and mean family income are statistically significant and positively correlated with the share of proficient students; additionally, the attendance also seems to have a statistically significant impact on the dependent variable. A one standard deviation increase in the ratio of nonpublic to public school enrollment is associated with a 1.5 percentage point increase in the share of students proficient in reading, a 1.22 percentage point increase in the share of students proficient in social science, and a 1.27 percentage point increase in the share of students proficient in science. ${ }^{12}$ The effect of relative nonpublic enrollment on public school test scores therefore varies between one-fifth and one-fourth of a standard deviation, depending upon the subject.

It is noteworthy that the remaining control variables with the exception of attendance rates, do not seem to be significantly associated with the public school test scores. For example,

\footnotetext{
$117.93 \times 0.325=2.57$.

12 Reading $=[4.53 \times 0.332=1.50]$, Social Studies $=[4.53 \times 0.270=1.22]$ and Science $=[4.53 \times 0.282=1.27]$.
} 
similar to Hall and Vedder (2003), we find that spending per pupil does not have a significant relationship with the learning outcomes of students. Likewise, neither do class size nor the salaries of instructional staff. Attendance, however, does appear to be very important in explaining district test scores, except in mathematics. A one standard deviation increase in a district's attendance rate would, other things equal, be expected to lead to a 2.05 percentage increase in the share of students proficient in science as measured by their test scores. ${ }^{13}$ This finding is consistent with previous studies such as Lamdin (1996). Given that there is substantial variation between the maximum and minimum values for this variable in West Virginia, it seems to be an area - in addition to school competition - where innovative attendance public policy might have a role to play. ${ }^{14}$

\section{Robustness Check}

Although it is quite possible that higher ratio of nonpublic school enrollment relative to public school enrollment increases academic performance in public schools, there exist possible confounds of this study. For example, there could be an ability-omission bias, such as that suggested by Belfield and Levin (2002), when it is only a certain type of students that choose to enroll in private schools, be it most or least able. To control for potential omitted variables and to possibly identify causality we employ an instrumental variables approach. As long as the variables that we are utilizing as instruments do not affect public school quality and are correlated with the share of nonpublic school enrollment, we should be able to identify the causal relationship.

\footnotetext{
$131.18 \times 1.739=2.05$.

${ }^{14}$ For more on reducing truancy and improving school attendance see Reid (2013).
} 
Similar to Hoxby (1994), Cohen-Zada (2009), and Carattini, Dills, Mulholland and Sederberg (2012), the instrumental variables that determine nonpublic school enrollment in this study are related to the presence of religious population by school district and as in Hoxby (2000) to the topology of each school district. School district borders in West Virginia match county borders; thus, we employ the value of church property in 1890 in each county, ratio of number of farms to each county area in 1890 , and share of county area occupied by water. ${ }^{15}$ All three of these variables are provided by U.S. Census Bureau: the first two from the 1890 U.S. Census (2014b; 2014c) and the last one from 2010 U.S. Census (2014d) gazetteer files. All three are plausibly orthogonal to current test scores but help explain levels of nonpublic enrollment by county.

A higher church value in 1890 would suggest a higher share of religious population that is able to afford the founding and funding of a private school. Since public school district borders are defined by county borders, they are not necessarily dictated by topology, as in Hoxby (2000). However, nonpublic school location might be affected by topology such as bodies of water and/or numerous elevation differences that would constitute an obstacle to getting to the nearest public school, stimulating demand for private education or homeschooling. Finally, counties with more rugged terrain were likely to have more farms in 1890 and therefore more private schools and home schooling today.

The results of the two stage least squares regression are presented in Table 4. The firststage F-statistic for all four regressions is 27.025 , showing that there is enough evidence to reject the null of weak instruments. The presence of multiple instruments allows us to test for over-

\footnotetext{
${ }^{15}$ In many states in the Northeast and Midwest, county borders and school district borders are not congruous (Ross et al. 2014). This makes West Virginia, despite the number of counties only equaling 55, a great state to investigate the effect of private school competition given the correspondence between county-level data for instruments and current county school districts.
} 
identifying restrictions. The J-statistic, reported at the bottom of columns 1-4 of Table 4, shows that there is not enough evidence to reject the null hypothesis that all the instruments are exogenous.

For all but one dependent variable, namely, proficiency in the mathematics section of the WESTEST2 assessment, the relationship of interest holds: a higher ratio of nonpublic school enrollment relative to public enrollment has a positive effect on public schools’ academic outcomes. The scale of the effect is not very different from the OLS results, however; for all sections of the test, the effect is somewhat smaller than the relationship shown in Table 3 . This suggests a potential upward bias in the coefficients provided by OLS technique. The influence of competition from nonpublic school enrollment ranges from an approximately 1.10 percentage points in social sciences to 1.35 percentage points in reading to. These results highlight the importance of dealing with potential endogeneity of nonpublic enrollment in studies of this type, as the quantitative effects are approximately 10 percent lower compared to the results found with a simple OLS estimation.

\section{Conclusion}

The argument for introducing market forces into the school education system has been a subject of discussion for quite some time now. The introduction of education vouchers, tax credits, charter schools, and magnet schools would promote the named forces. Their proponents believe that higher degrees of competition from nonpublic schools will require public schools to perform better than in a setting where there are very few substitutes for public school services (which is an outcome observed in many states). 
We attempt to test the argument empirically by using the data from West Virginia public school education system. We first find that increased competition as measured by nonpublic school enrollment to public school enrollment is associated with improved public school district test results. Employing an instrumental variables (IV) approach, we additionally show that the effect is potentially causal. Our IV results show that a one-standard deviation increase in the percentage of students in a county attending nonpublic schools (private or homeschooling) is associated with an increase of between 1.10 and 1.35 percentage points in the share of students proficient in various subjects as measured by public school test scores, other things being equal. These results suggest, at a minimum, that concern over efforts to increase nonpublic school enrollment in the State of West Virginia will not harm students remaining in the public schools. ${ }^{16}$

This study is to our best knowledge the first one to investigate the effect of competition on public school education outcomes in West Virginia. It joins a number of studies that find there to be a positive relationship between academic performance and competition. It builds upon much of the previous literature by adopting an IV strategy suggested by the economics of education literature in order to obtain a better idea of the causal relationship between nonpublic school attendance and public school performance.

\footnotetext{
${ }^{16}$ For example, see the arguments raised in opposition to a pilot program on public charter schools in West Virginia (Hodousek, 2015).
} 


\section{References}

Aaberge, R., \& Langørgen, A. (2003). Fiscal and spending behavior of local governments: Identification of price effects when prices are not observed. Public Choice, 117(1-2), $125-161$.

Akin, J. S., \& Lea, M. J. (1982). Microdata estimation of school expenditure levels: An alternative to the median voter approach. Public Choice, 38(2), 113-128.

Belfield, C. R., \& Levin, H. M. (2002). The effects of competition between schools on educational outcomes: A review for the United States. Review of Educational Research, 72(2), 279-341

Berends, M. (2014). The evolving landscape of school choice in the United States. In Handbook of Urban Education, edited by H.R. Milner IV and K. Lomotey. New York: Routledge, $451-473$

Burnell, B. S. (1991). The effect of school district structure on education spending. Public Choice, 69(3), 253-264.

Carattini, J. F., Dills, A. K., Mulholland, S. E., \& Sederberg, R. B. (2012). Catholic schools, competition, and public school quality. Economics Letters, 117(1), 334-336.

Cebula, R. J. (1977). An analysis of migration patterns and local government policy toward public education in the United States. Public Choice, 32(1), 113-121.

Cebula, R.J., Mixon, F.G., and Montez, M.A. (2015). Teachers' salaries and human capital, and their effects on academic performance: an institution-level analysis of Los Angeles County high schools. Journal of Economics and Finance 39(2), 347-356.

Cohen-Zada, D. (2009). An alternative instrument for private school competition. Economics of Education Review, 28(1), 29-37. 
Couch, J. F., Shughart, W. F., \& Williams, A. L. (1993). Private school enrollment and public school performance. Public Choice, 76(4), 301-312.

Denzau, A., \& Grier, K. (1984). Determinants of local school spending: Some consistent estimates. Public Choice, 44(2), 375-383.

Eide, E. R., \& Showalter, M. H. (2012). Sleep and student achievement. Eastern Economic Journal, 38(4), 512-524.

Forster, G. (2013). A win-win solution: The empirical evidence on school choice. Indianapolis: Friedman Foundation for Educational Choice.

Flowers, M. R. (1975). The possibility of double-peaked preference rankings for public school expenditures. Public Choice, 23(1), 81-85.

Geller, C. R., Sjoquist, D. L., \& Walker, M. B. (2006). The effect of private school competition on public school performance in Georgia. Public Finance Review, 34(1), 4-32.

Hall, J.C. (2000). Investment in Education: Public and Private Returns. Washington, D.C. Joint Economic Committee.

Hall, J.C. (2006). The dilemma of school finance reform. Journal of Social, Political, and Economic Studies, 31(2), 175-190.

Hall, J. C. (2007). Local school finance and productive efficiency: Evidence from Ohio. Atlantic Economic Journal 35(3), 289-301.

Hall, J. C., \& Vedder, R. K. (2003). The impact of private schools on public school performance: evidence from Ohio. Journal of Economics and Politics, 16(1), 99-114.

Hall, J.C. \& Leeson, P.T. (2010). Racial fractionalization and school performance. American Journal of Economics and Sociology, 69(2), 736-758.

Hodousek, C. (2015). Charter schools debated in House hearing. MetroNews, 10 March. 
Holcombe, R. G., \& Kenny, L. W. (2007). Evidence on voter preferences from unrestricted choice referendums. Public Choice, 131(1-2), 197-215.

Holcombe, R. G., \& Kenny, L. W. (2008). Does restricting choice in referenda enable governments to spend more? Public Choice, 136(1-2), 87-101.

Hoxby, C. M. (1994). Do private schools provide competition for public schools? National Bureau of Economic Research Working Paper No. w4978.

Hoxby, C. M. (2000). Does competition among public schools benefit students and taxpayers? American Economic Review, 90(5), 1209-1238

Lamdin, D. J. (1996). Evidence of student attendance as an independent variable in education production functions. Journal of Educational Research, 89(3), 155-162.

Marlow, M. L., \& Orzechowski, W. (1996). Public sector unions and public spending. Public Choice, 89(1-2), 1-16.

Misra, K., Grimes, P.W., \& Rodgers, K.E. (2012). Does competition improve public school efficiency? A spatial analysis. Economics of Education Review, 31(6), 1177-1190.

Ponzo, M. (2011). The effects of school competition on the achievement of Italian students. Managerial and Decision Economics, 32(1), 53-61.

Ravitch, D. (2011). The death and life of the great American school system: How testing and choice are undermining education. New York: Basic Books.

Reid, K. (2013). Managing school attendance: Successful intervention strategies for reducing truancy. Routledge.

Roby, D. E. (2004). Research on school attendance and student achievement: A study of Ohio schools. Educational Research Quarterly, 28(1), 3-16. 
Ross, J.M., Hall, J.C., \& Resh, W.G. (2014). Frictions in polycentric administration with noncongruent borders: Evidence from Ohio school district class sizes. Journal of Public Administration Research and Theory, 24(3), 623-649.

Sander, W. (1999). Private schools and public school achievement. Journal of Human Resources, 34(4), 697-709.

Simon, C. A., \& Lovrich, N. P. (1996). Private school enrollment and public school performance. Policy Studies Journal, 24(4), 666-675.

Thapa, A. (2013). Does private school competition improve public school performance? The case of Nepal. International Journal of Educational Development, 33(4), 358-366.

U.S. Census Bureau. (2014a). American Community Survey, 2006 - 2010 American Community Survey 5-Year Estimates. http://factfinder2.census.gov; (1 October 2014).

U.S. Census Bureau. (2014b). 1890 Census of Population and Housing, Volume 13: Report on Farms and Homes: Proprietorship and Indebtedness in the United States. https://www.census.gov/prod/www/decennial.html; (1 December 2014)

U.S. Census Bureau. (2014c). 1890 Census of Population and Housing, Volume 9: Report on Statistics of Churches in the United States in the United States. https://www.census.gov/prod/www/decennial.html; (1 December 2014).

U.S. Census Bureau. (2014d). 2010 Census Gazetter Files - Counties File. http://www.census.gov/geo/maps-data/data/gazetteer2010.html; (1 December 2014). Vedder, R.K., and Hall, J.C. (2000). Private school competition and public school teacher salaries. Journal of Labor Research, 21(1), 161-168. 
Verstegen, D. A., \& King, R. A. (1998). The relationship between school spending and student achievement: A review and analysis of 35 years of production function research. Journal of Education Finance, 24(2), 243-262.

West Virginia Department of Education. (2014). Data. https://wvde.state.wv.us/data/; (1 December 2014). 
Table 1. Summary descriptions and statistics of variables included in regressions

\begin{tabular}{|c|c|c|c|c|c|}
\hline Variable & Description & Mean & Std. Dev. & Min. & Max \\
\hline MATH & $\begin{array}{l}\% \text { of students proficient in the math section of the } \\
\text { test }\end{array}$ & 44.95 & 6.16 & 34.28 & 62.63 \\
\hline SOCSCI & $\begin{array}{l}\% \text { of students proficient in the social studies } \\
\text { section of the test }\end{array}$ & 34.96 & 6.22 & 18.29 & 49.19 \\
\hline SCI & $\begin{array}{l}\% \text { of students proficient in the science section of } \\
\text { the test }\end{array}$ & 39.52 & 6.28 & 26.37 & 54.51 \\
\hline$R E A D$ & $\begin{array}{l}\% \text { of students proficient in the reading section of } \\
\text { the test }\end{array}$ & 46.04 & 6.24 & 31.55 & 60.81 \\
\hline ENROLLRT & Ratio of private to public school enrolled students & 5.61 & 4.53 & 0.73 & 27.84 \\
\hline INCOME & Mean family income in 1000 s & 48.72 & 7.93 & 29.92 & 62.63 \\
\hline SPEND & Total current spending per pupil 1000s & 11.55 & 0.99 & 9.73 & 14.62 \\
\hline SIZE & Average class size & 15.92 & 1.30 & 12.30 & 18.30 \\
\hline$S A L A R Y$ & Average contracted salaries of teachers in 1000s & 44.95 & 1.40 & 41.33 & 48.54 \\
\hline ATTENDANCE & Attendance rate, \% & 97.13 & 1.18 & 92.89 & 99.08 \\
\hline \multicolumn{6}{|c|}{ Instrumental Variables } \\
\hline ALLPROP & Church property value in 1890 & 68543.2 & 99422.05 & 2000 & 657000 \\
\hline RATIOF & Ratio of number of farms to county area in 1890 & 3.44 & 1.59 & 0.00 & 6.76 \\
\hline WATER & County area occupied by water, \% & 1.03 & 1.14 & 0.02 & 6.1 \\
\hline
\end{tabular}

Note: the summary for each variable is based on 55 observations (the number of school districts in West Virginia). 
Table 2 OLS estimates from regressions of the percentage of students proficient in the math section of WESTEST2 on the ratio of private to public school enrollment

(1)

\begin{tabular}{lc}
\hline ENROLLRT & $0.282^{* *}$ \\
& $(0.115)$ \\
& \\
INCOME & $0.325^{* *}$ \\
& $(0.124)$ \\
SPEND & 0.0124 \\
& $(0.836)$ \\
SIZE & 0.726 \\
& $(0.790)$ \\
SALARY & 0.280 \\
ATTENDANCE & $(0.805)$ \\
& 0.633 \\
& $(0.599)$
\end{tabular}

Observations $\quad 55$

R-squared 0.390

Notes: *, **, and *** denote, respectively, significance at the $10 \%, 5 \%$, and $1 \%$ levels. White HAC standard errors are in parentheses. Dependent variable is MATH. Constants are included in the regressions, although not reported above 
Table 3. OLS estimates from regressions of the percentage of students proficient in the social studies, science, and reading sections of WESTEST2 on the ratio of private to public school enrollment

\begin{tabular}{lccc}
\hline & $(1)$ & $(2)$ & $(3)$ \\
& $R E A D$ & $S O S C I$ & $S C I$ \\
\hline ENROLLRT & $0.332^{* *}$ & $0.270^{* *}$ & $0.282^{* * *}$ \\
& $(0.125)$ & $(0.105)$ & $(0.102)$ \\
& & & \\
INCOME & $0.285^{* *}$ & $0.386^{* * *}$ & $0.366^{* * *}$ \\
SPEND & $(0.116)$ & $(0.0872)$ & $(0.119)$ \\
& 0.264 & 0.103 & -0.154 \\
SIZE & $(0.690)$ & $(0.637)$ & $(0.732)$ \\
& 0.287 & $0.887^{*}$ & 0.795 \\
SALARY & $(0.653)$ & $(0.503)$ & $(0.575)$ \\
& 0.730 & -0.079 & -0.704 \\
ATTENDANCE & $(0.617)$ & $(0.501)$ & $(0.649)$ \\
& $1.283^{*}$ & $1.796^{* * *}$ & $1.739 * * *$ \\
& $(0.653)$ & $(0.502)$ & $(0.601)$ \\
Observations & & & \\
R-squared & 55 & 55 & 55 \\
\hline
\end{tabular}

Notes: *, **, and *** denote, respectively, significance at the $10 \%, 5 \%$, and $1 \%$ levels. White HAC standard errors are in parentheses. Dependent variables are: READ, SOSCI, and SCI. Constants are included in the regressions, although not reported above. 
Table 4. 2SLS estimates from regressions of the percentage of students proficient in math, reading social studies, and science sections of WESTEST2 on the ratio of private to public school enrollment

\begin{tabular}{lcccc}
\hline & $(1)$ & $(2)$ & $(3)$ & $(4)$ \\
& MATH & READ & $\begin{array}{c}\text { SOCIAL } \\
\text { SCIENCES }\end{array}$ & SCIENCE \\
\hline ENROLLRT & 0.210 & $0.299^{* *}$ & $0.244^{* *}$ & $0.265^{* *}$ \\
& $(0.163)$ & $(0.126)$ & $(0.092)$ & $(0.118)$ \\
INCOME & & & & \\
& $0.331^{* *}$ & $0.287^{* *}$ & $0.386^{* * *}$ & $0.366^{* * *}$ \\
SPEND & $(0.131)$ & $(0.118)$ & $(0.087)$ & $(0.120)$ \\
& 0.100 & 0.305 & 0.257 & 0.000 \\
SIZE & $(0.859)$ & $(0.716)$ & $(0.635)$ & $(0.731)$ \\
& 0.602 & 0.230 & 0.790 & 0.708 \\
SALARY & $(0.783)$ & $(0.661)$ & $(0.522)$ & $(0.626)$ \\
& 0.290 & 0.734 & -0.112 & -0.742 \\
ATTENDANCE & $(0.824)$ & $(0.629)$ & $(0.528)$ & $(0.691)$ \\
& 0.623 & $1.278^{*}$ & $1.797 * * *$ & $1.742^{* * *}$ \\
& $(0.621)$ & $(0.658)$ & $(0.509)$ & $(0.599)$ \\
J-stat. & & & & \\
F-stat. (first stage) & 2.152 & 0.299 & 0.451 & 0.778 \\
Observations & & & $27.025^{* * *}$ & \\
\hline Notes: ${ }^{* *}$, and & 53 & 53 & 53 & 53 \\
\hline
\end{tabular}

Notes: ${ }^{*}, * *$, and $* * *$ denote, respectively, significance at the $10 \%, 5 \%$, and $1 \%$ levels. White heteroscedasticity-consistent standard errors are in parentheses. Dependent variable are: MATH, READ, SOSCI, and SCI. Constants are included in regressions though not reported. Instrumental variables are value of church property in 1890, ratio of number of farms in 1890 to county area, share of county area occupied by water 